\title{
Effects of water and nitrogen addition on vegetation carbon pools in a semi-arid temperate steppe
}

\author{
Junqiang Jia ${ }^{1,2} \cdot$ Yunshe Dong ${ }^{1}$ Yuchun $\mathrm{Qi}^{1} \cdot$ Qin Peng $^{1} \cdot$ Xinchao Liu ${ }^{1,3}$. \\ Liangjie Sun ${ }^{1,4} \cdot$ Shufang Guo ${ }^{1,2} \cdot$ Yunlong He $^{1,2} \cdot$ Congcong Cao ${ }^{1,2} \cdot$ \\ Zhongqing Yan ${ }^{1,2}$
}

Received: 30 June 2014 / Accepted: 12 March 2015/Published online: 31 July 2015

(C) Northeast Forestry University and Springer-Verlag Berlin Heidelberg 2015

\begin{abstract}
Global change will lead to increases in regional precipitation and nitrogen $(\mathrm{N})$ deposition in the semi-arid grasslands of northern China. We investigated the responses of vegetation carbon (C) pools to simulated precipitation and $\mathrm{N}$ deposition increases through field experiments in a typical steppe in Inner Mongolia. The treatments included $\mathrm{NH}_{4} \mathrm{NO}_{3}$ addition at concentrations of $0(\mathrm{CK}), 5$ (LN, low nitrogen), 10 (middle nitrogen, MN), and 20 (HN, high nitrogen) $\left(\mathrm{g} \mathrm{m}^{-2} \mathrm{a}^{-1}\right)$ with and without water. After three consecutive years of treatment, from 2010 to 2012, water addition did not significantly change the size of the
\end{abstract}

Project funding: This work was financially supported by the National Natural Science Foundation of China (Nos. 41373084, 41330528, and 41203054), and the Special Fund for Agro-scientific Research in the Public Interest (No. 201203012).

The online version is available at http://www.springerlink.com

Corresponding editor: Zhu Hong

Yunshe Dong

dongys@igsnrr.ac.cn

$\triangle$ Yuchun Qi

qiyc@igsnrr.ac.cn

1 Key Laboratory of Land Surface Pattern and Simulation, Institute of Geographic Sciences and Natural Resources Research, Chinese Academy of Sciences, Beijing 100101, People's Republic of China

2 University of the Chinese Academy of Sciences, Beijing 100049, People's Republic of China

3 Grassland Research Institute, Inner Mongolia Academy of Agricultural \& Animal Husbandry Sciences, Huhehot 010031, People's Republic of China

4 College of Land and Environment, Shenyang Agricultural University, Shenyang 110866, People's Republic of China total vegetation $\mathrm{C}$ pools, but it significantly decreased the ratio of root:shoot $(\mathrm{R}: \mathrm{S})(P=0.05)$ relative to controls. By contrast, $\mathrm{N}$ addition significantly increased the total vegetation $\mathrm{C}$ pools. The $\mathrm{C}$ pools in the $\mathrm{LN}, \mathrm{MN}$ and $\mathrm{HN}$ treatments increased by 22,39 and $44 \%$, respectively. MN produced the largest effect among the $\mathrm{N}$ concentrations, although differences between $\mathrm{N}$-added treatments were not significant $(P>0.05)$. N addition significantly reduced the ratio of root:shoot $(\mathrm{R}: \mathrm{S})(P=0.03)$. However, there were no significant interactive effects of water and $\mathrm{N}$ addition on the vegetation $\mathrm{C}$ pools.

Keywords Vegetation carbon pools - Increasing precipitation - Nitrogen addition - Interactive effect · Temperate steppe

\section{Introduction}

Photosynthetic carbon (C) fixation by vegetation is one of the major processes controlling the $\mathrm{C}$ input to terrestrial ecosystems (Joiner et al. 2011). Soil organic C, the largest $\mathrm{C}$ reservoir in many terrestrial ecosystems (Schlesinger 1977), is primarily plant derived (Kuzyakov and Domanski 2000; Ryals and Silver 2013). Over the past 50 years, terrestrial vegetation has absorbed $25-30 \%$ of anthropogenic $\mathrm{CO}_{2}$ emissions, with the $\mathrm{C}$ stored in vegetation and soil (Reichstein et al. 2013). Terrestrial gross primary production, which is approximately $(123 \pm 8) \mathrm{Pg} \mathrm{a}^{-1}$, is the largest global component of $\mathrm{C}$ flux and directly influences the $\mathrm{C}$ budget of terrestrial ecosystems (Malhi 2012; Beer et al. 2010). Understanding changes in plant C-fixation capacity and its main influencing factors are important areas of $\mathrm{C}$ cycle research. 
At present, the rapid changes in atmospheric $\mathrm{CO}_{2}$ concentration, temperature, precipitation, and nitrogen $(\mathrm{N})$ deposition have drawn global attention (Galloway and Cowling 2002; IPCC 2007). As described in the fifth IPCC assessment report, the response and feedback of the $\mathrm{C}$ cycle to future climatic and environmental changes have been fully accounted for in most of the earth system models of the Coupled Model Intercomparison Project Phase 5 (CMIP5) (Yu and Piao 2014). Among all the global change factors, water and soil nutrient availability are important limiting factors for plant growth in most terrestrial ecosystems, particularly in arid and semi-arid ecosystems (Belnap 2001; Austin et al. 2004; Guo et al. 2006; Zhao et al. 2009). However, to date, most studies of the $\mathrm{C}$ cycle processes of terrestrial ecosystems occurring under the scenario of global change have focused on soil $\mathrm{C}$ sequestration and emission (Craine and Gelderman 2011; Jin et al. 2007; Asner et al. 2004; Groenigen et al. 2011), and few have focused on vegetation $\mathrm{C}$ fixation. An improved understanding of the response and sensitivity of terrestrial vegetation $\mathrm{C}$ fixation to global environmental change can increase our ability to accurately predict the $\mathrm{C}$ budgets of terrestrial ecosystems.

In recent years, increasing $\mathrm{N}$ deposition and shifts in precipitation regimes have become global trends (Galloway and Cowling 2002; IPCC 2007). Asia, including China, is one of the three regions with the highest $\mathrm{N}$ deposition rates in the world, due to high levels of fertilizer application, fossil fuel combustion, and other human activities (Dentener et al. 2006; Zhang et al. 2008). Meanwhile, a global increase of approximately $0.5-1 \%$ in precipitation per decade is predicted over this century (IPCC 2001), and in northern China, annual precipitation is predicted to increase by $14-155 \mathrm{~mm}$ by the end of the century, according to the simulations of 13 IPCC global climate models (Jiang et al. 2008). Changing patterns of $\mathrm{N}$ deposition and precipitation can greatly change plant growth and vegetation $\mathrm{C}$ pools in terrestrial ecosystems (Potts et al. 2006; Yu et al. 2009; Thomas et al. 2010); however, there remains considerable uncertainty regarding the effects of increasing water and $\mathrm{N}$ inputs. For example, many studies have reported that additional $\mathrm{N}$ should increase the aboveground $\mathrm{C}$ pools in grasslands (Wedin and Tilman 1996; Foster and Gross 1998; Xia and Wan 2008). Gough et al. (2000) found that the aboveground biomass increased by $50 \%$ under $\mathrm{N}$ fertilization in North American herbaceous ecosystems; however, others studies reported either no effects (Bai et al. 2010) or negative effects (Vitousek and Howarth 1991). Water availability is critical to all life (Wu 2011) and is another important factor influencing the primary production of ecosystems. In an Amazon rainforest, Phillips et al. (2009) found that before 2005, plots exhibited a long-term net increase of approximately
$0.89 \mathrm{Mg} \mathrm{ha}^{-1} \mathrm{a}^{-1}$ ) in aboveground biomass, but after encountering intense drought in 2005 , this rate declined by $2.39 \mathrm{Mg} \mathrm{ha}^{-1} \mathrm{a}^{-1}$ in the 28 plots suffering the greatest water deficits. In arid and semi-arid ecosystems, the limitations of precipitation on plant growth will be even more pronounced (Sims and Singh 1978; Le Houérou et al. 1988; Bai et al. 2004; Dalgleish and Hartnett 2006; Swemmer et al. 2007; Van Auken 2009). However, more rainfall does not necessarily enhance growth. Wang and Zhou (2004) found that as annual rainfall exceeded $350 \mathrm{~mm}$, aboveground net primary productivity (ANPP) in Leymus chinensis grassland declined. These studies indicate that there are complex effects of increasing $\mathrm{N}$ deposition and increasing precipitation on terrestrial vegetation. In addition to the main effects of water or $\mathrm{N}$, global change involves concurrent changes in multiple factors, which could yield complex interactive effects (Dukes et al. 2005; Bell et al. 2008). However, little information exists on the interactive effects of water and $\mathrm{N}$ on vegetation $\mathrm{C}$ pools in arid and semi-arid ecosystems. Thus, study of the vegetation $\mathrm{C}$ pool responses to changes in water and $\mathrm{N}$ availability is urgently needed.

In China, grassland is the largest terrestrial ecosystem, covering $40 \%$ of the total land area (Chen and Wang 2000). The total biomass of grassland vegetation in China is approximately $1044.76 \mathrm{Tg}$ (Piao et al. 2004). Approximately $78 \%$ of grasslands in China are located in temperate arid and semi-arid regions where the fragile environments and intensive human activity increase the sensitivity of local ecological processes to environmental change relative to other ecosystems (Warren et al. 1996; Wen 1996). We studied the main and interactive effects of increasing precipitation and $\mathrm{N}$ deposition on vegetation $\mathrm{C}$ pools in a temperate, semi-arid typical steppe in Inner Mongolia, China. Our objectives were to (1) identify the differential responses of vegetation $\mathrm{C}$ pools to increased $\mathrm{N}$ and water availability and (2) determine whether there are significant interactive effects of water and $\mathrm{N}$ on vegetation C pools.

\section{Materials and methods}

\section{Experimental site}

The experiment site was a Leymus chinensis steppe $\left(43^{\circ} 33^{\prime} 10^{\prime \prime} \mathrm{N}, 116^{\circ} 40^{\prime} 29^{\prime \prime} \mathrm{E}\right.$; $1265 \mathrm{~m}$ above mean sea level) in Baiinxile pasture, Xilin River Basin, Inner Mongolia, China. The site was near the Inner Mongolian Grassland Ecosystem Research Station of the Chinese Academy of Sciences (Fig. 1). The Xilin River Basin is in the core area of the Northeast China Transect (NECT) for the International Geosphere-Biosphere Program (IGBP) for the study 
Fig. 1 Map of the sampling site in the Xilin River Basin of Inner Mongolia, China

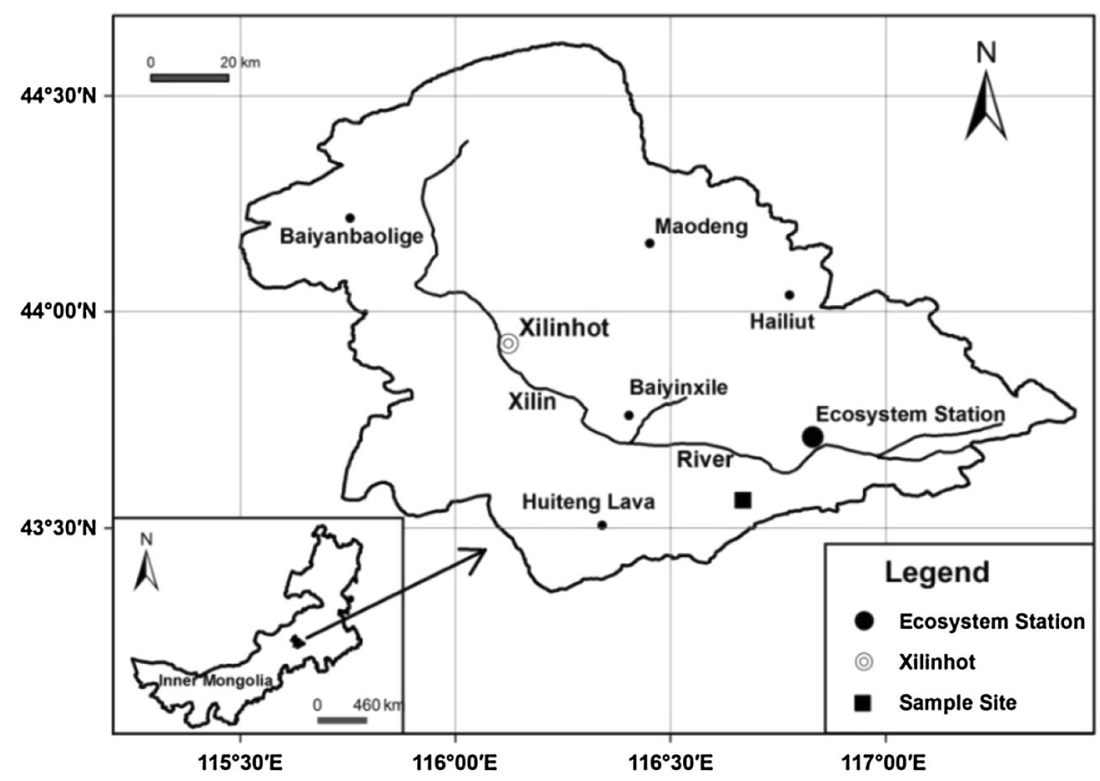

of global change. The temperate typical steppe along this transect is representative of grasslands in China and Eurasia (Zhang et al. 1997; Qi et al. 2014). The climate is semi-arid, temperate with mean annual temperature of $-0.4{ }^{\circ} \mathrm{C}$, ranging from $-21.41{ }^{\circ} \mathrm{C}$ in January to $18.53{ }^{\circ} \mathrm{C}$ in July. Mean annual precipitation is approximately $354 \mathrm{~mm}$ (70 \% falls between July and September). The plant community was dominated by L. chinensis, Stipa grandis, Agropyron michnoi, and Cleistogenes squarrosa. The experimental site had been used for grazing prior to enclosure, with a grazing intensity of approximately 2.25 sheep per hectare. The soil is classified as chestnut soil according to Chinese soil classification or as Calcic-orthic Aridisol according to soil taxonomic classification. The soil is comprised of $60 \%$ sand, $21 \%$ clay, and $19 \%$ silt. The depths of the soil profiles were $100-150 \mathrm{~cm}$, with a 20-30 cm humus layer. Characteristics of the soils in the experimental plots are listed in Table 1.

\section{Experimental design}

In May 2010, an area of steppe $51 \times 78 \mathrm{~m}$ with flat topography and relatively uniform vegetation distribution was fenced. Forty $8 \mathrm{~m} \times 8 \mathrm{~m}$ plots separated by $1 \mathrm{~m}$ buffers were demarcated, with eight treatments and five replicates assigned at random among the plots to examine the main and interactive effects of water and $\mathrm{N}$ addition. The eight treatments included two water treatment levels (added/not added) and four $\mathrm{N}$ treatment levels; CK, low nitrogen (LN, $\left.5 \mathrm{~g} \mathrm{~m}^{-2} \mathrm{a}^{-1}\right)$, middle nitrogen (MN, $10 \mathrm{~g} \mathrm{~m}^{-2} \mathrm{a}^{-1}$ ), and high nitrogen ( $\mathrm{HN}, 20 \mathrm{~g} \mathrm{~m}^{-2} \mathrm{a}^{-1}$ ).

Each year, the equivalent of $51.7 \mathrm{~mm}$ rainfall, representing approximately $15 \%$ of the mean annual rainfall at the study site, was applied to the added water treatment plots. This amount was based on the predicted future increase of $12-18 \%$ by the end of the 21 st century, according to 13 IPCC-AR4 models for northern China (Jiang et al. 2008). From 2010 to 2012, the water was manually added each month from June to September using backpack sprayers. The water input each month was calculated as the proportion of rainfall in that month relative to the total amount over the 4 months. This amount was then divided by two and applied twice per month (usually mid-month and late in the month) to ensure each addition was equivalent to the median amount of the daily rainfall in this area. For the $\mathrm{N}$ treatments, $\mathrm{NH}_{4} \mathrm{NO}_{3}$ was ground into

Table 1 Characteristics of $L$. chinensis steppe soil

\begin{tabular}{lllllll}
\hline $\begin{array}{l}\text { Soil sampling depths } \\
(\mathrm{cm})\end{array}$ & $\begin{array}{l}\text { Total organic } \mathrm{C} \\
\left(\mathrm{g} \mathrm{kg}^{-1}\right)\end{array}$ & $\begin{array}{l}\text { Total N } \\
\left(\mathrm{g} \mathrm{kg}^{-1}\right)\end{array}$ & $\mathrm{C} / \mathrm{N}$ ratio & $\begin{array}{l}\mathrm{NH}_{4}^{+}-\mathrm{N} \\
\left(\mathrm{mg} \mathrm{kg}^{-1}\right)\end{array}$ & $\begin{array}{l}\mathrm{NO}_{3}^{-}-\mathrm{N} \\
\left(\mathrm{mg} \mathrm{kg}^{-1}\right)\end{array}$ \\
\hline $0-10$ & $16.52 \pm 1.05$ & $1.43 \pm 0.27$ & $11.55 \pm 1.51$ & $3.98 \pm 0.03$ & $\begin{array}{l}\mathrm{Bulk} \text { density } \\
\left(\mathrm{g} \mathrm{cm}^{-3}\right)\end{array}$ \\
$10-20$ & $14.05 \pm 1.41$ & $1.35 \pm 0.28$ & $10.40 \pm 1.17$ & $3.91 \pm 0.08$ & $3.38 \pm 0.14$ \\
$20-30$ & $13.83 \pm 1.65$ & $1.21 \pm 0.29$ & $11.43 \pm 1.47$ & $3.84 \pm 0.52$ & $3.85 \pm 0.21$ & $1.28 \pm 0.01$ \\
\hline
\end{tabular}

Data are means $( \pm$ SEs, $n=3)$ 
fine powder, weighed, and then spread evenly within each plot. The fertilizer was applied twice annually, usually in late June and in late July. The $\mathrm{N}$ addition levels were chosen based on the current atmospheric $\mathrm{N}$ deposition level and its possible change in the next 50 years, simultaneously referred to the existing experiments in China and abroad (Chen et al. 2005; Arens and Sullivan 2008; Tu et al. 2009; Thomas et al. 2010). We applied large doses of $\mathrm{N}$ and water over a short period based on the assumption that this method effectively mimiced small inputs of $\mathrm{N}$ and water over longer periods that would result from climate change.

\section{Vegetation sampling and analysis}

Vegetation surveys were conducted in mid-August 2012, the time of peak biomass, after 3 years of water and $\mathrm{N}$ addition. There were five repetitions of every treatment, and we randomly sampled three quadrats in each repeated plot at each sampling period, so there were 15 samples for each treatment. For measurements of aboveground biomass, vegetation was cut at ground level and sorted into living plants and standing dead plants. Surface litter was subsequently collected. Belowground biomass was measured by digging soil pits $\left(40 \times 40 \times 40 \mathrm{~cm}^{3}\right)$ at the same locations where the aboveground biomass had been removed. Roots within $0-40 \mathrm{~cm}$ depth accounted for $80-90 \%$ of the total belowground biomass in our study area (Xiao 2010). Root samples were collected separately from two layers at $0-20$ and $20-40 \mathrm{~cm}$ depth in each sampling plot. For each layer, the soil was removed from the root samples by gently washing with tap water using a $2 \mathrm{~mm}$ sieve.

All plant samples (aboveground living plant, aboveground standing dead plant, surface litter, and root) were oven-dried at $80{ }^{\circ} \mathrm{C}$ to constant weight to determine the dry biomass and then were pulverized to test $\mathrm{C}$ content. Organic $\mathrm{C}$ content was determined using a total organic $\mathrm{C}$ analyzer (Elementar vario TOC cube, Germany). The vegetation $\mathrm{C}$ pools for the aboveground components (aboveground living plant, standing dead plant and surface litter) and the belowground root for each plot were estimated by multiplying the sample biomass by the organic $\mathrm{C}$ concentration for each component.

Statistical analyses were performed using SPSS 17.0 software. Statistically significant differences between $\mathrm{N}$ addition treatments were investigated using one-factor analysis of variance (ANOVA). A two-way ANOVA was used to test for significant effects of the main factors; i.e., $\mathrm{N}$ addition $(\mathrm{N})$, water addition $(\mathrm{W})$, and their interaction $(\mathrm{N} \times \mathrm{W})$. Graphs were prepared using Excel (2010).

\section{Results}

\section{Responses of vegetation $C$ pools to water addition}

After 3 years of simulated increasing rainfall, each component of the vegetation $\mathrm{C}$ pools for the control (CK) and water-added treatment (WCK) were calculated (Fig. 2). The $\mathrm{C}$ pools of the aboveground living plants and litter were 12.55 and $25.09 \%$ higher, respectively, in the wateraddition plots than in the CK treatment plots (Fig. 2a), while the standing dead $\mathrm{C}$ pool in the WCK treatment was $5.52 \%$ lower than in the CK treatment. For the belowground components, water addition reduced the $\mathrm{C}$ pools of roots at $0-20$ and $20-40 \mathrm{~cm}$ by approximately 5.19 and $4.56 \%$, respectively, relative to controls. Differences in the $\mathrm{C}$ pools of the plant components between the treatments
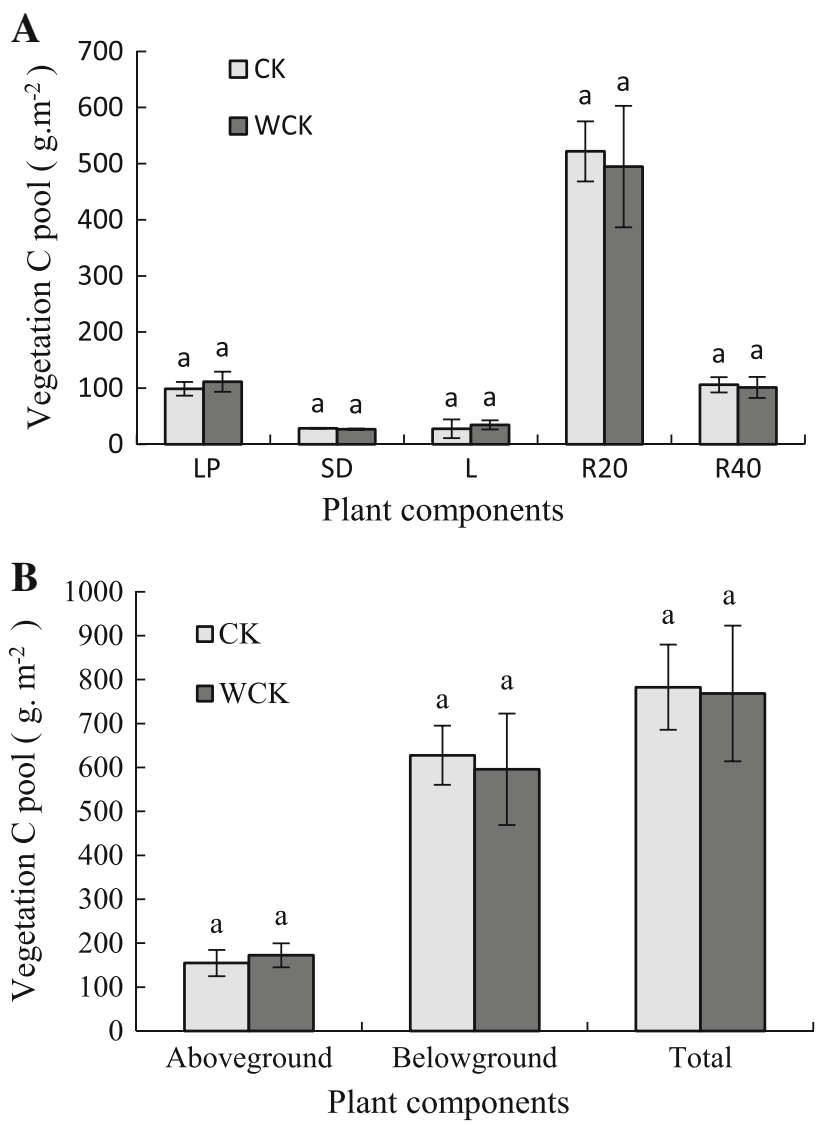

Fig. 2 Effect of added water on C pools by plant component. Bars with different small letters denote treatments that differ significantly at $P<0.05$. Error bars indicate the standard errors of the mean $(n=15)$. Aboveground $\mathrm{C}$ pool is the sum of the living plant $\mathrm{C}$ pool, the standing dead $\mathrm{C}$ pool and the litter $\mathrm{C}$ pool; belowground $\mathrm{C}$ pool is the sum of the root $C$ pools at $0-20$ and $20-40 \mathrm{~cm}$ depth. The aboveground $\mathrm{C}$ pool plus the belowground $\mathrm{C}$ pool equals the total vegetation C pool. R20 is Root $(0-20 \mathrm{~cm})$; R40 is Root $(20-40 \mathrm{~cm})$; $L P$ living plant, $S D$ standing dead, $L$ litter 
with and without water addition were not significant. The $\mathrm{C}$ pool of all aboveground components combined was $11.46 \%$ higher in the water-added plots than in the control plots, whereas the belowground and total $\mathrm{C}$ pool was 5.09 and $1.81 \%$ lower, respectively (Fig. 2b). These differences were not significant.

\section{Effects of $\mathbf{N}$ addition on vegetation $\mathbf{C}$ pools}

The vegetation $\mathrm{C}$ pools of the different plant components in the fertilized and unfertilized plots are shown in Fig. 3. The plots receiving the $\mathrm{CK}, \mathrm{LN}, \mathrm{MN}$ and $\mathrm{HN}$ treatments had 0 , 5, 10 and $20 \mathrm{~g} \mathrm{~m}^{-2} \mathrm{a}^{-1}$ added, respectively, and no water added. The $\mathrm{C}$ pool of the aboveground living plants was significantly higher $(P<0.05)$ in fertilized plots than in unfertilized plots. The $\mathrm{C}$ pools of the aboveground living plants were $181.75 \mathrm{~g} \mathrm{~m}^{-2}(\mathrm{HN}), 176.56 \mathrm{~g} \mathrm{~m}^{-2}(\mathrm{MN})$, and $154.28 \mathrm{~g} \mathrm{~m}^{-2}(\mathrm{LN})$, values 84,79 , and $56 \%$ higher, respectively, than the corresponding $\mathrm{CK}$ value (98.83 $\mathrm{g} \mathrm{m}^{-2}$ ). However, the $\mathrm{C}$ pools did not differ significantly by added- $\mathrm{N}$ treatment level. $\mathrm{N}$ addition had a negligible effect on the $\mathrm{C}$ pools of the standing dead, litter and $20-40 \mathrm{~cm}$ root components. However the $\mathrm{C}$ pool of roots at $0-20 \mathrm{~cm}$ depth $\left(709.43 \mathrm{~g} \mathrm{~m}^{-2}\right)$ in the $\mathrm{MN}$ treatment was significantly higher $(P=0.02)$ than that of the CK plots $\left(521.80 \mathrm{~g} \mathrm{~m}^{-2}\right)$. The $\mathrm{C}$ pools at this root depth were also higher in the $\mathrm{LN}\left(597.31 \mathrm{~g} \mathrm{~m}^{-2}\right)$ and $\mathrm{HN}$ $\left(663.37 \mathrm{~g} \mathrm{~m}^{-2}\right)$ treatments than in the control treatment but not significantly so. Moreover, the root $C$ pool at 0-20 cm depth did not differ significantly between the $\mathrm{N}$-added treatments.

The aboveground, belowground and total $\mathrm{C}$ pool values showed a similar pattern among the different $\mathrm{N}$ treatments, decreasing in the order $\mathrm{MN}>\mathrm{HN}>\mathrm{LN}>\mathrm{CK}$; the highest amount of $\mathrm{C}$ pool was observed in the $\mathrm{MN}$, not $\mathrm{HN}$, treatments (Fig. 4). The mean values of total $\mathrm{C}$ pool in the LN, MN and HN treatments were 953.81, 1090.10 and

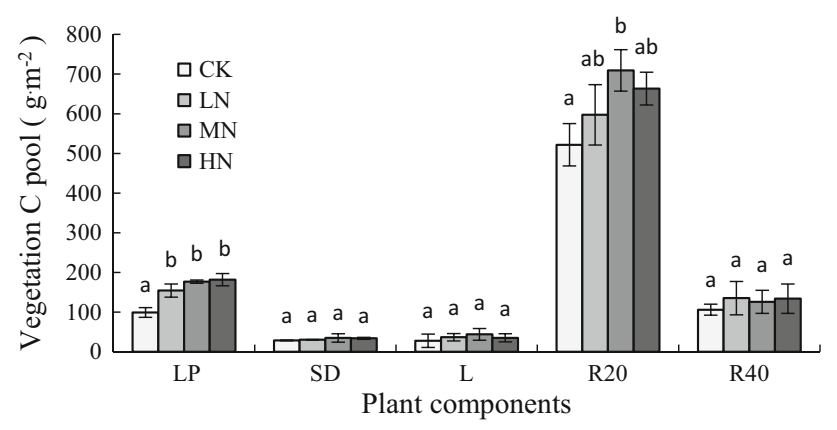

Fig. 3 Vegetation $\mathrm{C}$ pools by $\mathrm{N}$ treatment. Bars with different small letters denote treatments that differ significantly at $P<0.05$. Error bars indicate standard errors of the mean $(n=15)$. R20 is Root $(0-20 \mathrm{~cm})$; R40 is Root $(20-40 \mathrm{~cm}) ; L P$ living plant, $S D$ standing dead, $L$ litter

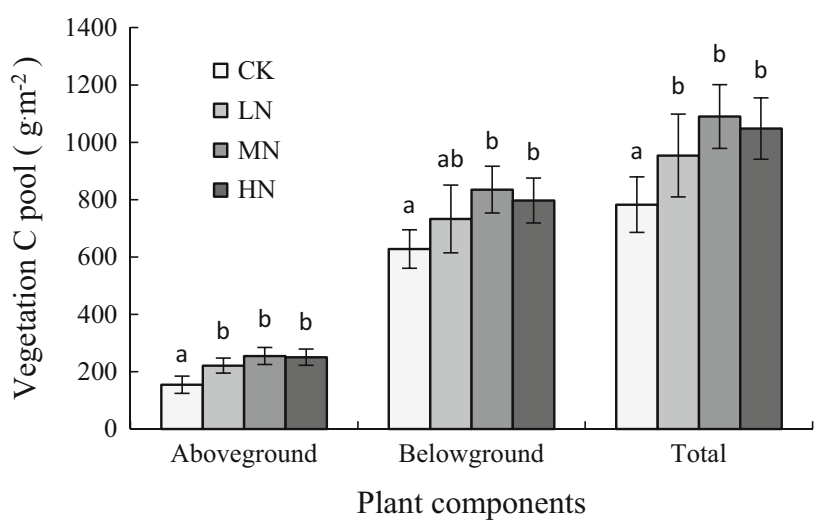

Fig. 4 Effects of added $\mathrm{N}$ on aboveground, belowground and total vegetation $\mathrm{C}$ pools. Bars with different small letters denote treatments that differ significantly at $P<0.05$. Error bars indicate the standard errors of the mean $(n=15)$

$1047.77 \mathrm{~g} \mathrm{~m}^{-2}$, respectively; values $1.22,1.39$ and 1.34 times higher, respectively, than that of the $\mathrm{CK}$ treatment (782.64 $\mathrm{g} \mathrm{m}^{-2}$ ). The mean values of aboveground $\mathrm{C}$ pool in the $\mathrm{CK}, \mathrm{LN}, \mathrm{MN}$ and $\mathrm{HM}$ treatments were 154.86, $221.27,255.02$ and $250.61 \mathrm{~g} \mathrm{~m}^{-2}$, respectively. Moreover, both the total $\mathrm{C}$ pool and the aboveground $\mathrm{C}$ pool were significantly higher $(P<0.05)$ in the three fertilized plots than in the unfertilized plots, but neither differed significantly between fertilizer treatments. Belowground $\mathrm{C}$ pool was significantly higher in the $\mathrm{MN}\left(835.08 \mathrm{~g} \mathrm{~m}^{-2}\right)$ and $\mathrm{HN}$ $\left(797.16 \mathrm{~g} \mathrm{~m}^{-2}\right)$ treatments $(P<0.05)$ than in the $\mathrm{CK}$ treatment $\left(627.78 \mathrm{~g} \mathrm{~m}^{-2}\right)$, with no significant differences observed between LN (732.53 $\left.\mathrm{g} \mathrm{m}^{-2}\right)$ and any of the other treatments.

\section{Interactive effects of $\mathrm{N}$ and water addition on vegetation $\mathrm{C}$ pools}

The results of the two-way ANOVA are shown in Table 2. The $\mathrm{C}$ pools of each plant component were not significantly affected by the addition of water, although the $P$ values of the living plant $(0.07)$ and $0-20 \mathrm{~cm}$ root layer components (0.06) approached significance. The $\mathrm{C}$ pools of the standing dead plant, litter and $20-40 \mathrm{~cm}$ root components were not significantly $(P>0.05)$ affected by $\mathrm{N}$ addition. However, there were significant effects of $\mathrm{N}$ addition on the $\mathrm{C}$ pools of the living plant and $0-20 \mathrm{~cm}$ root components, as well as on aboveground, belowground and total $\mathrm{C}$ pool $(P<0.05)$. The effects of the interaction between $\mathrm{N}$ and water on the total $\mathrm{C}$ pool and on the $\mathrm{C}$ pool of individual plant components were insignificant.

The ratio of root:shoot (R:S) is a key parameter in many global terrestrial C cycling models (Wang et al. 2010). Comparing R:S among the different water and $\mathrm{N}$ treatments, it is apparent that within each $\mathrm{N}$ treatment, $\mathrm{R}: \mathrm{S}$ was 
Table 2 Results $(F$ - and $P$ values) of the two-way ANOVA testing for effects of $\mathrm{N}$ addition $(\mathrm{N})$, water addition $(\mathrm{W})$, and their interaction $(\mathrm{W} \times \mathrm{N})$ on vegetation $\mathrm{C}$ pools (15 replicates)

\begin{tabular}{|c|c|c|c|c|c|c|c|c|}
\hline \multirow[t]{2}{*}{ Factors } & \multicolumn{2}{|c|}{ Living plant } & \multicolumn{2}{|c|}{ Standing dead } & \multicolumn{2}{|l|}{ Litter } & \multicolumn{2}{|c|}{ Root $(0-20 \mathrm{~cm})$} \\
\hline & $F$ & $P$ & $F$ & $P$ & $F$ & $P$ & $F$ & $P$ \\
\hline W & 3.61 & 0.07 & 0.21 & 0.65 & 1.33 & 0.27 & 3.84 & 0.06 \\
\hline $\mathrm{N}$ & 18.98 & 0.00 & 1.09 & 0.38 & 1.67 & 0.21 & 5.84 & 0.01 \\
\hline $\mathrm{W} \times \mathrm{N}$ & 0.11 & 0.95 & 0.00 & 1.00 & 0.42 & 0.74 & 0.15 & 0.93 \\
\hline \multirow[t]{2}{*}{ Factors } & \multicolumn{2}{|c|}{ Root $(20-40 \mathrm{~cm})$} & \multicolumn{2}{|c|}{ Aboveground } & \multicolumn{2}{|c|}{ Belowground } & \multicolumn{2}{|l|}{ Total } \\
\hline & $F$ & $P$ & $F$ & $P$ & $F$ & $P$ & $F$ & $P$ \\
\hline W & 0.71 & 0.41 & 3.26 & 0.09 & 2.75 & 0.11 & 0.75 & 0.40 \\
\hline $\mathrm{N}$ & 0.34 & 0.80 & 15.46 & 0.00 & 6.62 & 0.00 & 16.23 & 0.00 \\
\hline $\mathrm{W} \times \mathrm{N}$ & 0.89 & 0.47 & 0.06 & 0.98 & 0.36 & 0.79 & 0.28 & 0.84 \\
\hline
\end{tabular}

\begin{tabular}{llll}
\hline Treatments & \multicolumn{2}{l}{ R:S ratio } & Without water/with water \\
\cline { 2 - 3 } & Without water addition & With water addition & \\
\hline CK & $6.07 \pm 0.71 \mathrm{a}^{*}$ & $5.29 \pm 0.51 \mathrm{a}$ & 1.15 \\
$\mathrm{LN}$ & $4.97 \pm 0.53 \mathrm{~b}^{*}$ & $3.91 \pm 0.38 \mathrm{~b}$ & 1.27 \\
$\mathrm{MN}$ & $4.51 \pm 0.42 \mathrm{~b}^{*}$ & $3.85 \pm 0.36 \mathrm{~b}$ & 1.17 \\
$\mathrm{HN}$ & $4.52 \pm 0.33 \mathrm{~b}^{*}$ & $3.74 \pm 0.34 \mathrm{~b}$ & 1.21 \\
Average & 5.02 & 4.19 & 1.20 \\
CV $(\%)$ & 14.56 & 17.42 & \\
\hline
\end{tabular}

* Values followed by the same letter within the same column are not significantly different at $P<0.05$; values in the 'Without water addition' column followed by an asterisk are significantly different from their corresponding (same row) values in the 'With water application' at $P<0.05$
Table 3 Mean ratio of root:shoot (R:S) by water and $\mathrm{N}$ treatments consistently lower in the water-added treatments than in treatments without added water (Table 3). The R:S of the different $\mathrm{N}$ treatments without water were $19.61 \%$ higher, on average, than those with added water. Water addition reduced the R:S in each $\mathrm{N}$ treatment. Moreover, water addition increased the variation coefficient $(\mathrm{CV})$ of the R:S among the different $\mathrm{N}$ treatments. Regardless of water addition, R:S values for fertilized plots were all significantly lower than for CK plots. Similarly, N addition also reduced $\mathrm{R}: \mathrm{S}$ values of the vegetation.

These analyses showed that the effect of $\mathrm{N}$ addition on $\mathrm{R}: \mathrm{S}$ varied with water treatment and suggested that water and $\mathrm{N}$ availability may have had an interactive effect. However, two-way ANOVA indicated that the R:S ratio was significantly $(P<0.05)$ affected by both water and $\mathrm{N}$ addition, but not by the interaction of $\mathrm{N}$ and water (Table 4).

\section{Discussion}

\section{Response of vegetation $\mathrm{C}$ pools to water addition}

Addition of water had no significant effect on aboveground, belowground or total $\mathrm{C}$ pools (Table 2). Water
Table 4 Results ( $F$ - and $P$ values) of two-way ANOVA of the effects of $\mathrm{N}$ addition $(\mathrm{N})$, water addition $(\mathrm{W})$, and their interaction $(\mathrm{W} \times \mathrm{N})$ on $\mathrm{R}: \mathrm{S}$ ratios (15 replicates)

\begin{tabular}{lll}
\hline Factors & $F$ & $P$ \\
\hline Water addition & 4.67 & 0.05 \\
$\mathrm{~N}$ addition & 3.71 & 0.03 \\
Interaction $(\mathrm{W} \times \mathrm{N})$ & 0.01 & 1.00 \\
\hline
\end{tabular}

addition significantly reduced R:S (Table 3 ). This result may be due to the higher-than-average level of natural precipitation in our experimental year. Wang and Zhou (2004) studied the same area and reported that the cumulative precipitation from October to the subsequent August was the most important factor influencing annual ANPP, and that when accumulated precipitation approached $350 \mathrm{~mm}$, additional precipitation no longer promoted aboveground plant growth and could even inhibit growth. The accumulated precipitation at our study site between October 2011 and August 2012 was $404.5 \mathrm{~mm}$, and in 2012, annual precipitation was $514.1 \mathrm{~mm}$, both exceeding the $350 \mathrm{~mm}$ threshold. The increase in natural rainfall alleviated water restrictions on plant growth and led to the insignificant effect of increasing artificial precipitation. 
Although the responses of plant component $\mathrm{C}$ pools were not affected by added water, the insignificant increases in aboveground $\mathrm{C}$ pools and the decrease in belowground $\mathrm{C}$ pools together caused significant reduction in $\mathrm{R}: \mathrm{S}$ values when water was added. Similar results were reported by Dukes et al. (2005) for a California grassland. This decrease in R:S reflects the change in plant growth in response to the change in soil moisture. When soil moisture content is increased by natural or artificial rainfall, plants allocate more energy to aboveground growth, acquiring more light energy to satisfy the requirements of plant photosynthesis. In addition, root respiration also increases under favorable soil moisture conditions, reducing the root biomass accordingly (Xu and Zhou 2005; Tian et al. 2010; Wen et al. 2010).

\section{Response of vegetation $\mathrm{C}$ pools to $\mathrm{N}$ addition}

$\mathrm{N}$ is a major limiting nutrient for plant growth in many terrestrial ecosystems (Carvalhais et al. 2011; LeBauer and Treseder 2008). In our study, addition of $\mathrm{N}$ increased aboveground $\mathrm{C}$ pools. Relative to the control treatment, the aboveground $\mathrm{C}$ pools of $\mathrm{LN}, \mathrm{MN}$ and $\mathrm{HN}$ increased by approximately 43, 65, and $62 \%$, respectively; however, aboveground $\mathrm{C}$ pools did not differ by $\mathrm{N}$ treatment. Similar results have been reported in other studies (Foster and Gross 1998; Xia and Wan 2008; Qi et al. 2011). Qi et al. (2011) found that L. chinensis aboveground biomass increased by $39 \%$ under $\mathrm{N}$ fertilization in a potted field control experiment. Among the above-ground plant components, the living plant $\mathrm{C}$ pool increased significantly, whereas the $\mathrm{C}$ pools of standing dead and litter did not. These results might be due to the lag in response of standing dead and litter to increasing $\mathrm{N}$ deposition relative to living plants, although increasing living plant biomass will, over time, lead to higher biomass of standing dead and litter. The relatively rainy weather conditions of 2012 also accelerated litter decomposition and the leaching of easilydecomposed litter compounds (Peng et al. 2014).

In many terrestrial ecosystems, added $\mathrm{N}$ decreases root primary production because plants allocate more resources to the canopy to compete for light when soil nutrients are more available (Bardgett et al. 1999; Hautier et al. 2009). Zeng et al. (2010) found that $\mathrm{N}$ fertilization resulted in lower root $\mathrm{C}$ pools, but Harpole et al. (2007) found that $\mathrm{N}$ addition had no effect on root biomass production. However, our results are not fully consistent with previous findings. Our belowground $\mathrm{C}$ pools were greater in all $\mathrm{N}$ treatments than in the control treatment, and significantly greater for $\mathrm{MN}$ and $\mathrm{HN}$ (Fig. 4). Similar results were reported by Pan et al. (2005) and Qi et al. (2011). These differences among studies may be due to different soil moisture conditions. Some studies have found that water availability is the most important limiting factor for plant growth in arid and semi-arid grasslands (Bai et al. 2010; Rao and Allen 2010). Under drought stress conditions, $\mathrm{N}$ addition cannot effectively promote plant growth because drought severely restricts the mobility of $\mathrm{N}$ in soil (Chen et al. 2005), although it may improve water use to mitigate the effects of decreased plant photosynthesis (Bardgett et al. 1999). However, $\mathrm{N}$ availability will become an important limiting factor when water availability is not restricted. Additional $\mathrm{N}$ will have a positive effect on plant growth in most N-limited terrestrial ecosystems, but progressive $\mathrm{N}$ application generally increases shoot growth more consistently and to a greater extent than root growth, leading to a decrease in the R:S ratio (Dukes et al. 2005). In our experimental year of 2012, the total precipitation from May to August was $32 \%$ higher than the average annual rainfall during that period. Therefore, water was no longer a factor restricting the positive effects of $\mathrm{N}$ on plant growth, which led to an insignificant positive effect on plant biomass (Fig. 2), and an insignificant interaction between water and $\mathrm{N}$ (Table 2). The R:S ratios of the $\mathrm{N}$-added plots were lower than those of controls, indicating that the internal distribution ratio of the vegetation $\mathrm{C}$ pool changed due to increasing $\mathrm{N}$ input. Because decomposition rates of aboveground and belowground plant components differ (Giese et al. 2009), this change in the internal distribution of plant biomass due to $\mathrm{N}$ addition will inevitably affect the $\mathrm{C}$ input from plants to soil.

The highest levels of aboveground, belowground and total vegetation $\mathrm{C}$ pools were recorded for the $\mathrm{MN}$ treatment, rather than the HN treatment (Fig. 4). Addition of optimal amounts of $\mathrm{N}$ should promote leaf photosynthesis and plant growth but addition of excessive $\mathrm{N}$ might reduce plant photosynthetic capacity because of the self-shading effect (Brown et al. 1996) or because of nutrient imbalances in $\mathrm{N}, \mathrm{P}, \mathrm{Mn}$ and $\mathrm{Mg}$, which would decrease leaf protein concentrations and Rubisco activity, resulting in inhibited leaf photosynthesis (Nakaji et al. 2001). Some researchers have also found that addition of large quantities of anthropogenic $\mathrm{N}$ may increase soil acidity, leading to increased loss of cations and decreased availability of phosphorus and other limiting nutrients, ultimately reducing plant production (Maston et al. 1999; Li et al. 2003; Song et al. 2010).

\section{Conclusions}

Addition of water did not have a significant impact on total or plant component $\mathrm{C}$ pools. $\mathrm{N}$ addition significantly increased total vegetation $\mathrm{C}$ pools and $\mathrm{MN}$ addition had the most significant promoting effect among the $\mathrm{N}$ treatments. Addition of both water and $\mathrm{N}$ significantly reduced $\mathrm{R}: \mathrm{S}$ 
ratios. Changes in soil moisture and $\mathrm{N}$ availability with increasing precipitation and $\mathrm{N}$ deposition on China's temperate grasslands could change the distribution of vegetation $\mathrm{C}$ pools and accordingly change the $\mathrm{C}$ input from plants to soil. Interactive effects between water and $\mathrm{N}$ addition on vegetation $\mathrm{C}$ pools were not significant. $\mathrm{R}: \mathrm{S}$ ratios of treatments with addition of both water and $\mathrm{N}$ were, however, lower than those with addition of $\mathrm{N}$ alone. To explore the micro-scale effects of water and $\mathrm{N}$ addition on plant $\mathrm{C}$ fixation potential and to more accurately predict grassland $\mathrm{C}$ budgets, studies conducted at the leaf scale on plant photosynthesis under scenarios of anticipated global change should receive more attention in future research.

Acknowledgments We gratefully acknowledge the Inner Mongolia Grassland Ecosystem Research Station (IMGERS) for their field assistance.

\section{References}

Arens SJT, Sullivan PF (2008) Nonlinear responses to nitrogen and strong interactions with nitrogen and phosphorus additions drastically alter the structure and function of a high arctic ecosystem. J Geophys Res 113:G03S09. doi:10.1029/ 2007JG000508

Asner GP, Elmore AJ, Olander LP, Martin RE, Harris AT (2004) Grazing systems, ecosystem responses and global change. Annu Rev Environ Resour 29:261-299

Austin AT, Yahdjian L, Stark JM, Belnap J, Porporato A, Norton U (2004) Water pulses and biogeochemical cycles in arid and semiarid ecosystems. Oecologia 141:221-235

Bai YF, Han XG, Wu JG, Chen ZZ, Li LH (2004) Ecosystem stability and compensatory effects in the Inner Mongolia grassland. Nature 431:181-184

Bai YF, Wu JG, Clark CM, Naeem S, Pan QM, Huang JH, Zhang LX, Han XG (2010) Tradeoffs and thresholds in the effects of nitrogen addition on biodiversity and ecosystem functioning: evidence from Inner Mongolia grasslands. Glob Chang Biol $16: 358-372$

Bardgett RD, Mawdsley JL, Edwards S, Hobbs PJ, Rodwell JS, Davies WJ (1999) Plant species and nitrogen effects on soil biological properties of temperate upland grasslands. Funct Ecol 13:650-660

Beer C, Reichstein M, Tomelleri E, Ciais P (2010) Terrestrial gross carbon dioxide uptake: global distribution and co-variation with climate. Science 329:834-838

Bell C, Mclntyre N, Cox S, Tissue D, Zak J (2008) Soil microbial responses to temporal variations of moisture and temperature in a Chihuahuan Desert grassland. Microb Ecol 56:153-167

Belnap J (2001) Microbes and microfauna associated with biological soil crusts. In: Belnap J, Lange OL (eds) Biological soil crusts: structure, function, and management. Springer, Berlin, pp $167-174$

Brown KR, Thompson WA, Camm EL (1996) Effects of N addition rates on the productivity of Picea sitchensis, Thuja plicata, and Tsuga heterophylla seedlings. Trees 10:198-205

Carvalhais LC, Dennis PG, Fedoseyenko D, Hajirezaei MR, Borriss R (2011) Root exudation of sugars, amino acids and organic acids by maize as affected by nitrogen, phosphorus, potassium and iron deficiency. J Plant Nutr Soil Sci 174:3-11
Chen ZZ, Wang SP (2000) Typical grassland ecosystem in China. Science Press, Beijing, p 1

Chen SP, Bai YF, Zhang LX, Han XG (2005) Comparing physiological responses of two dominant grass species to nitrogen addition in Xilin River Basin of China. Environ Exp Bot 53:65-75

Craine JM, Gelderman TM (2011) Soil moisture controls on temperature sensitivity of soil organic carbon decomposition for a mesic grassland. Soil Biol Biochem 43:455-457

Dalgleish HJ, Hartnett DC (2006) Below-ground bud banks increase along a precipitation gradient of the North American Great Plains: a test of the meristem limitation hypothesis. New Phytol 171:81-89

Dentener F, Drevet J, Lamarque JF (2006) Nitrogen and sulfur deposition on regional and global scales: a multi-model evaluation. Glob Biogeochem Cycles 20:GB4003. doi:10.1029/ 2005GB002672

Dukes JS, Chiariello NR, Cleland EE (2005) Responses of grassland production to single and multiple global environmental changes. PLoS Biol 3:1829-1837

Foster BL, Gross KL (1998) Species richness in a successional grassland: effects of nitrogen enrichment and plant litter. Ecology 79:2593-2602

Galloway JN, Cowling EB (2002) Reactive nitrogen and the world: 200 years of change. Ambio 31:64-71

Giese M, Gao YG, Zhao Y, Pan QM, Lin S, Peth S, Brueck H (2009) Effects of grazing and rainfall variability on root and shoot decomposition in a semi-arid grassland. Appl Soil Ecol 41:8-18

Gough L, Osenberg CW, Gross KL, Collins SL (2000) Fertilization effects on species density and primary productivity in herbaceous plant communities. Oikos 89:428-439

Groenigen KJ, Osenberg CW, Hungate BA (2011) Increased soil emissions of potent greenhouse gases under increased atmospheric $\mathrm{CO}_{2}$. Nature 475:214-216

Guo R, Wang XK, Ouyang ZY, Li YN (2006) Spatial and temporal relationships between precipitation and ANPP of four types of grasslands in northern China. J Environ Sci 18(5):1024-1030

Harpole WS, Goldstein L, Aicher R (2007) Resource limitation. In: D'Antonio C, Corbin J, Stromberg M (eds) Ecology and management of California grassland. University of California Press, Berkeley, pp 119-127

Hautier Y, Niklaus PA, Hector A (2009) Competition for light causes plant biodiversity loss after eutrophication. Science 324:636-638

IPCC (2001) Climate change 2001: the scientific basis. Cambridge University Press, Cambridge, $\mathrm{p} 4$

IPCC (2007) Climate change 2007: the physical science basis. Cambridge University Press, Cambridge, pp 27-940

Jiang ZH, Zhang X, Wang J (2008) Projection of climate change in China in the 21 st century by IPCC-AR 4 models. Geogr Res 27(4):787-799

Jin Z, Qi YC, Dong YS (2007) Diurnal and seasonal dynamics of soil respiration in desert shrubland of Artemisia Ordosica on Ordos Plateau of Inner Mongolia, China. J For Res 18(3):231-235

Joiner JY, Yoshida Y, Vasilkov AP, Yoshida Y, Corp LA, Middleton EM (2011) First observations of global and seasonal terrestrial chlorophyll fluorescence from space. Biogeosciences 8:637-651

Kuzyakov Y, Domanski G (2000) Carbon input by plants into the soil. J Plant Nutr Soil Sci 163:421-431

Le Houérou HN, Bingham RL, Skerbek W (1988) Relationship between the variability of primary production and the variability of annual precipitation in world arid lands. J Arid Environ 15:1-18

LeBauer DS, Treseder KK (2008) Nitrogen limitation of net primary productivity in terrestrial ecosystems is globally distributed. Ecology 89:371-379 
Li DJ, Mong JM, Fang YT (2003) Impact of nitrogen deposition on forest plants. Acta Ecol Sin 23(9):1892-1900

Malhi Y (2012) The productivity, metabolism and carbon cycle of tropical forest vegetation. J Ecol 100:65-75

Maston PA, McDowell WH, Townsen AR (1999) The globalization of $\mathrm{N}$ deposition: ecosystem consequences in tropical environments. Biogeochemistry 46:67-83

Nakaji T, Fukami M, Dokiya Y (2001) Effects of high nitrogen load on growth, photosynthesis and nutrient status of Cryptom eria japonica and Pinus densiflora seedlings. Trees-Struct Funct 15(8):453-461

Pan QM, Bai YF, Han XG, Yang JC (2005) Effects of nitrogen additions on a leymus chinensis population in a typical steppe of Inner Mongolia. Acta Phytoecol Sin 29:311-317

Peng Q, Qi YC, Dong YS (2014) Decomposing litter and the C and N dynamics as affected by $\mathrm{N}$ additions in a semi-arid temperate steppe, Inner Mongolia of China. J Arid Land 6(4):432-444

Phillips OL, Aragão LEOC, Lewis SL, Fisher JB (2009) Drought sensitivity of the Amazon rainforest. Science 323:1344-1347

Piao SL, Fang JY, He JS, Xiao Y (2004) Spatial distribution of grassland biomass in China. Acta Phytoecol Sin 28(4):491-498

Potts DL, Huxman TE, Cable JM (2006) Antecedent moisture and seasonal precipitation influence the response of canopy-scale carbon and water exchange to rainfall pulses in a semi-arid grassland. New Phytol 170:849-860

Qi Y, Huang YM, Wang Y (2011) Biomass and its allocation of four grassland species under different nitrogen levels. Acta Ecol Sin 31(18):5121-5129

Qi YC, Liu XC, Dong YS (2014) Differential responses of short-term soil respiration dynamics to the experimental addition of nitrogen and water in the temperate semi-arid steppe of Inner Mongolia, China. J Environ Sci 26:834-845

Rao LE, Allen EB (2010) Combined effects of precipitation and nitrogen deposition on native and invasive winter annual production in California deserts. Oecologia 62:1035-1046

Reichstein M, Bahn M, Ciais P, Frank D, Mahecha MD, Sonia I, Martin W (2013) Climate extremes and the carbon cycle. Nature 500(5):287-295

Ryals R, Silver WL (2013) Effects of organic matter amendments on net primary productivity and greenhouse gas emissions in annual grasslands. Ecol Appl 23:46-69

Schlesinger (1977) Carbon balance in terrestrial detritus. Annu Rev Ecol Syst 8:51-81

Sims PL, Singh JS (1978) The structure and function of ten western North American grasslands. III. Net primary production, turnover and efficiencies of energy capture and water use. J Ecol 66:573-597

Song CJ, Ma KM, Qu LY (2010) Interactive effects of water, nitrogen and phosphorus on the growth, biomass partitioning and wateruse efficiency of Bauhinia faberi seedlings. J Arid Environ 2010:1-10

Swemmer AM, Knapp AK, Snyman HA (2007) Intra-seasonal precipitation patterns and above-ground productivity in three perennial grasslands. J Ecol 95:780-788

Thomas RQ, Canham CD, Weathers KC, Goodale CL (2010) Increased tree carbon storage in response to nitrogen deposition in the US. Nat Geosci 3:13-17

Tian YS, Guo YY, Zhang PD (2010) Relationship of regional net primary productivity and related meteorological factors. Pratacult Sci 27(2):8-17
Tu LH, Hu TX, Huang LH (2009) Response of soil respiration to simulated nitrogen deposition in Pleioblastus Amarus forest, rainy area of west China. Chin J Plant Ecol 33(4):728-738

Van Auken OW (2009) Causes and consequences of woody plant encroachment into western North American grasslands. J Environ Manag 90:2931-2942

Vitousek PM, Howarth RW (1991) Nitrogen limitation on land and in the sea: how can it occur? Biogeochemistry 13:87-115

Wang YH, Zhou GS (2004) Responses of temporal dynamics of aboveground net primary productivity of Leymus chinensis community to precipitation fluctuation in Inner Mongolia. Acta Ecol Sin 24(6):1140-1145

Wang L, Niu KC, Yang YH (2010) Patterns of above- and belowground biomass allocation in China's grasslands: evidence from individual-level observations. Sci China Ser C 53(7):851-857

Warren A, Sud YC, Rozanov B (1996) The future of deserts. J Arid Environ 32:75-89

Wedin DA, Tilman D (1996) Influence of nitrogen loading and species composition on the carbon balance of grasslands. Science 274:1720-1723

Wen MZ (1996) The status and prospect of grassland source utilization in Chinese eco-agriculture. Agro-Environ Dev 13:14-18

Wen X, Hou XY, Mu HB (2010) Effects of irrigation amount on alfalfa productivity in south of Beijing. Pratacult Sci 27(4):73-77

Wu ZT (2011) Responses of terrestrial ecosystems to temperature and precipitation change: a meta-analysis of experimental manipulation. Glob Chang Biol 17:927-942

Xia JY, Wan SQ (2008) Global response patterns of terrestrial plant species to nitrogen addition. New Phytol 179:428-439

Xiao SS (2010) The responses of carbon fixation and soil organic carbon pool to external nitrogen input in the temperate semi-arid grassland ecosystem. University of Chinese Academy of Sciences, Beijing, pp 48-50

$\mathrm{Xu}$ ZZ, Zhou GS (2005) EV ects of water stress and high nocturnal temperature on photosynthesis and nitrogen level of a perennial grass Leymus chinensis. Plant Soil 269:131-139

Yu L, Piao SL (2014) Key scientific points on carbon and other biogeochemical cycles from the IPCC fifth assessment report. Progressus Inquisitiones De Mutatione Climatis 10(1):33-36

Yu ZY, Zeng DH, Jang FQ (2009) Responses of biomass to the addition of water, nitrogen and phosphorus in Keerqin sandy grassland, Inner Mongolia, China. J For Res 20(1):23-26

Zeng DH, Li LJ, Fahey TJ, Yu ZY, Fan ZP, Chen FS (2010) Effects of nitrogen addition on vegetation and ecosystem carbon in a semi-arid grassland. Biogeochemistry 98:185-193

Zhang XS, Zhou GS, Gao Q, Yang DA, Ni J, Wang Q (1997) Northeast China Transect (NECT) for global change studies. Earth Sci Front 4:145-151

Zhang W, Mo JM, Fang YT, Lu XK, Wang H (2008) Effects of nitrogen deposition on the greenhouse gas fluxes from forest soils. Acta Ecol Sin 28:2309-2319

Zhao GY, Liu JS, Wang Y, Dou JX, Dong XY (2009) Effects of elevated $\mathrm{CO}_{2}$ concentration and nitrogen supply on biomass and active carbon of freshwater marsh after two growing seasons in Sanjiang Plain, Northeast China. J Environ Sci 21:1393-1399 